\title{
Factors Affecting Commercialization of Home Garden Vegetables in Sri Lanka
}

\author{
Musthapha Mufeeth ${ }^{1}$ S(D) $ه$, A.M. Nihab ${ }^{2} 8$ (D) and Noordeen Nusrathali ${ }^{3}$ (iD) \\ ${ }^{123}$ Department of Biosystems Technology, South Eastern University of Sri Lanka, Sri Lanka \\ $\triangle$ Corresponding Author: Musthapha Mufeeth, E-mail: mufeeth.mohammathu@seu.ac.lk
}

\section{ARTICLE INFORMATION}

Received: January 08, 2021

Accepted: March 25, 2021

Volume: 3

Issue: 1

DOI: $10.32996 /$ jefas.2021.3.1.5

\section{KEYWORDS}

Home garden, vegetable, commercialization, Tobit regression, Sri Lanka

\section{ABSTRACT}

The study was carried out to find the factors affecting commercialization of vegetable that produced from the home garden and its average level of commercialization. A structured questionnaire and field observation techniques were used to collect data from 232 randomly selected home gardeners in the South East part of Sri Lanka. The Tobit regression model was applied to study the significant factors that influenced home garden vegetables' commercialisation. The present study found that the average home garden vegetable commercialization level was 32.3 per cent. Further, the commercialization significantly $(p<0.05)$ had a negative impact on the farmer's level of education, family income, size of the family, health consciousness of home gardener, and losses by the pest and disease whereas the marital status, the number of family labours involved in home gardening and institutional supports significantly increase the commercialization. The research recommends that public and private sector involvement is needed to support through the training program and advisory services to control pest and disease attack. Further, the study area needs to be appreciated and promoted via appropriate policy intervention strategies to develop a good structure value chain and market.

\section{Introduction}

Home garden is a garden surrounding a residence that provides various goods and services to household members in rural areas. A home garden is usually a small-scale supplemental food production method for residents and contributes to stabilizing the ecosystem as it is a natural, multilayered ecosystem (Hoogerbrugge \& Fresco, 1993). This small-scale production method provides plant and animal products either not obtainable, affordable, or readily available through retail markets. Household gardens tend to be located close to dwelling for security, convenience, and special care. They occupy land marginal to field production and labour marginal to major household economic activities. Featuring ecologically adapted and complementary species, household gardens are marked by low capital input and simple technology (Niñez, 1987). As well as, home garden fulfilling the social, economic, and cultural needs of people. Therefore, it contributes to a family's diet and may even provide additional income. Sri Lankan home garden contains annual, biennial, and perennial crops as well as livestock earing. Within such home gardens, plants with various canopy depths are found and then classified as multi-species and multi-storied cropping systems. However, the home garden's basic structures varied from place to place, based on their ecological, socio-economic and cultural factors. Home gardening is usually done in a tiny piece of land near the family residence. The grown products normally applied to the family members' routine nutritional supplements in Ampara district. People cultivate vegetables with low inputs and practices as organic farms. Leafy vegetables, brinjal, okra, chili, bitter guard, luffa, pumpkin, and cassava are the famously grown vegetable in the home garden in this study area.

Commercialization is the mechanism of acceptance into the market of a new product or manufacturing system in which its success is measured by the degree to which it is accepted by the consumer (Hebard, 2016). Commercialization of agricultural production is an endogenous process and is driven by economic growth, urbanization, and booming of agricultural sector (Pingali \& Rosegrant, 1995). The commercialization of agricultural products has complicated ties with food security and nutrition. Further, it impacts per capita income, men and women's income (Babu et al., 2014).

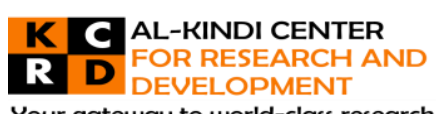

Your gateway to world-class research

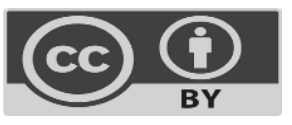

Published by Al-Kindi Center for Research and Development. Copyright (c) the author(s). This open access article is distributed under a Creative Commons Attribution (CC-BY) 4.0 license 
Agricultural commercialization has the most significant impacts on the rural economy since yield obtained from home garden cultivation are commercialized for their income. The significant amount of land area in Ampara district thus, seven percentages of the land area was used for home garden activities, and a portion of the yield was commercialized (Divisional Secretariat Ampara District, 2018). However, the commercialization of vegetables and factors affecting commercializing the home garden vegetable has not been studied. Therefore, it is very important to do a comprehensive study to make important home garden vegetable commercialization policies. Therefore, the present study investigates the factors affecting commercialization of home garden vegetables in Ampara district.

\section{Review of Literature}

The commercialization of a product depends on numerous social, economic and environmental factors of a business. Specially commercializing agricultural goods and services is impacted by the same three main factors of a farm (Mariyono et al., 2017). Several studies explored the commercialization of agricultural products. The influence of farmers' demographic characteristics and institutional supports available to the farm on the commercialization of vegetables were explored (Mariyono, 2018). The availability of extension service to a farm positively influences the level of commercialization (Rubhara \& Mudhara, 2019). The market characteristics such as distance to market and farmers' demographic characteristics had been identified factors that impact the extent of commercialization of urban fam vegetables (Akinlade et al., 2016). Similarly, Abdullah et al. (2019) investigated the determinant factors influencing smallholder rice farmers and discovered that farmers' household characteristics such as the size of the household and off-farm income and institutional supports like access to credit, affected the commercialization. Jerop, Owuor, and Mshenga (2018). and Ochieng et al. (2016) concluded that the commercialization of finger millet was determined by farm loss due to pest and disease, the farmer's education level, and farm size.

Farms owned by males were relatively highly commercialized thus, the gender of farmers influences the level of commercialization (Kabiti et al., 2016; Rubhara \& Mudhara, 2019). Further, the studies on the commercialization of animal farm products found that guinea fowl's commercialisation was impacted by the availability of extension services, input quality, and used technology for production (Moreki \& Radikara, 2013). The experience of a farmer, losses due to outbreak, input quantity used, number of family labour involvement, product losses, and training or advisory services significantly affect the commercialization of indigenous chicken (Mufeet et al., 2018; Maumburudze, et al., 2016; Mufeeth, Korale, \& Rthnasekara, 2015). Identified influential factors of the commercialization of agricultural farm products retrieved from the literature have been summarized as a conceptual framework illustrated below in Fig.01.

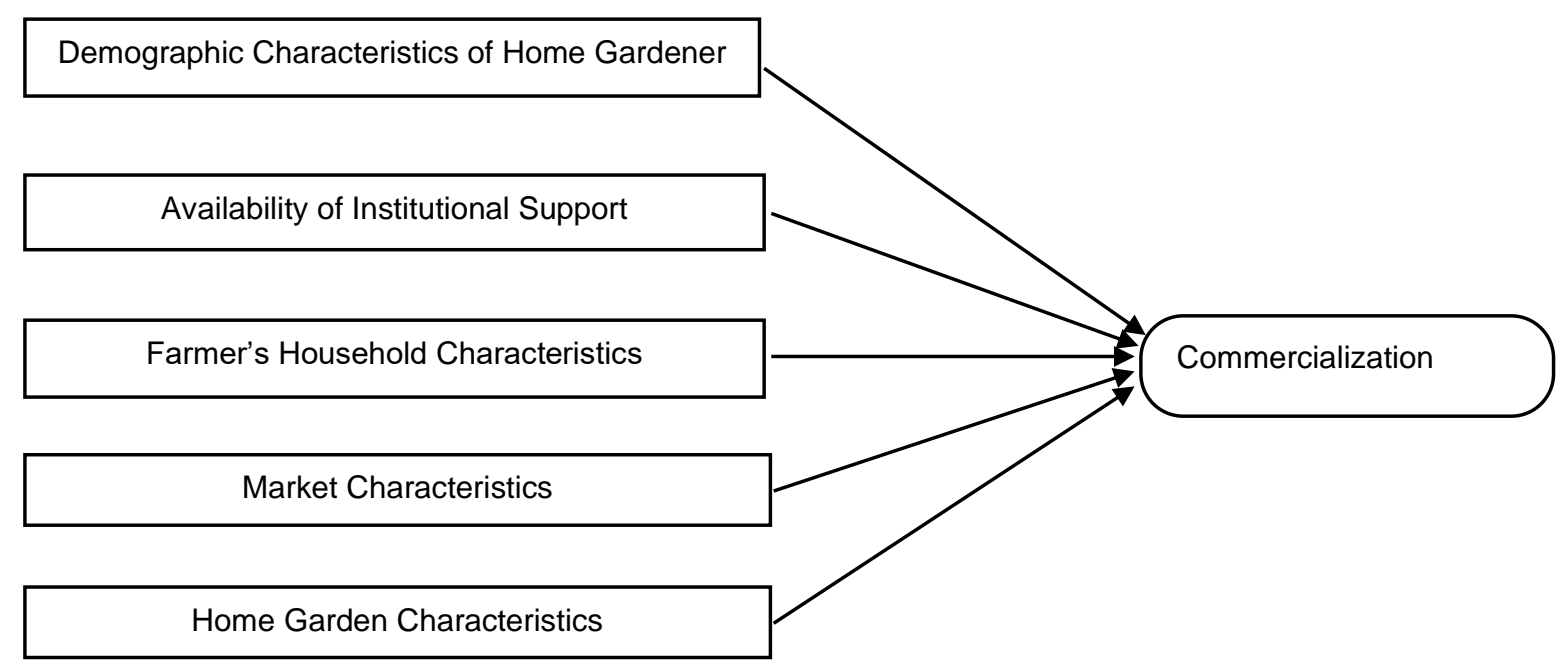

Figure 1: Conceptual Framework for home garden vegetable commercialization

\section{Materia and Methods}

\subsection{Location of the Study}

The study was carried out in Ampara District located in the South-Eastern part of Sri Lanka. Where the average annual rainfall and temperature are $1858 \mathrm{~mm}$ and $27.2^{\circ} \mathrm{C}$ (Department of Census and Statistics, 2018). The region is located in the country's dry zone, and the prominent crop cultivated is paddy. 


\subsection{Data Collection}

The present list of home gardeners was collected from regional agrarian service centres in Ampara district. The survey was conducted from March 2019 to July 2019 and the responses were collected from 232 randomly selected home gardeners. Further, the home garden characteristics were observed during the survey time. The quantitative research approach was used to collect and analyze data, from a responsible extension officer. This was done to strengthen and validate the data collected through the questionnaire.

\subsection{Analytical Mode}

The independent variable known as the commercialisation level was measured using the commercialization index applied by Govereh, Jayne, \& Nyoro (1999) and Strasberg et al. (1999) smallholder vegetable commercialization studies. The home garden vegetable commercialization (Cl) index was calculated as follows (Equation 1).

$$
\mathrm{CI}=\frac{\mathrm{GVS}}{\mathrm{GVP}}
$$

Where;

$\mathrm{Cl}$ - Commercialization index of vegetables produced in the home garden

GVS - Gross value of vegetable sale in home garden (in Rs)

GVP - Gross value of vegetable produced in home garden (in Rs)

Merely, the index measures the extent to which the home garden vegetable production is oriented towards the market (Osmani et al., 2014). The commercialization index takes the values ranging from 0 (totally subsistence-oriented home garden) to 1 (highly commercialized home garden. The present study used the Tobit regression model to identify the factors that determine commercialization. Tobit regression model is the most popular censored regression model suitable for estimating upper or lower limit dependent variables against independent variables (Liu, Wang, \& Wu, 2013; Walker, Norton et al., 2019). Thus, the value of $\mathrm{Cl}$ is censored, where 0 is the lowest limit and 1 is the upper limit (Wooldridge, 2013). The Tobit model can be specified as follows (Equation 2).

$$
C I_{j}^{*}=\beta_{0}+\sum_{m=1}^{k} \beta_{m} X_{j m}+\mu_{j}, \quad \mu_{j} \sim N\left(0, \sigma^{2}\right)
$$

Where $\mathrm{Cl}_{j}^{*}$ is a latent variable representing the commercialization of $j^{\text {th }}$ home garden thus, the dependent variable $\mathrm{Y}=\mathrm{Cl}^{*}$ when $\mathrm{Cl}^{*} \geq 0$, and $\mathrm{Y}$ $=0$ when $\mathrm{Cl}^{*}=0 . \beta_{\mathrm{m}}$ is unknown parameters need to be estimated. $\mathrm{X}_{\mathrm{jm}}$ is a vector of explanatory variables related to $\mathrm{j}^{\text {th }}$ home garden which are known constant and hypothesized as determinants of commercialization. $\mu_{\mathrm{j}}$ is an error term that is independently and normally distributed, with mean zero and a constant variance $\sigma^{2}$. The aforementioned Tobit regression model was estimated using STAT version 13 statistical package. Further, the descriptive and frequency analysis was done using Microsoft Excel 2016.

\section{Results and Discussion}

The mean commercialization index for the vegetables produced in the home garden in Ampara district was 0.323 . Thus, out of the total production 32.3 percentage of vegetables were commercialized to the market by the home garden vegetable producers and the households consumed the balance of the harvests. More than fifty per cent of people who were practising the home garden were in 40 to 50 age range and 73.25 per cent of them were males. The young people were not interested in home gardening as they focused more on other jobs and studies. Intriguingly, around 83 per cent of the home garden practitioners had daily wage jobs as the other income sources (Fig. 02). The result revealed that the home garden act as an income source and an instrument of food security for lower-income level people (Dilrukshi et al., 2013; Reginald et al., 2012). The average commercialization of home garden vegetables was high for daily wage people compared to monthly fixed salary home gardeners. Especially, both the divorced and widowed female home gardeners commercialized their products than the married and single female home gardeners (Fig. 03.a). 


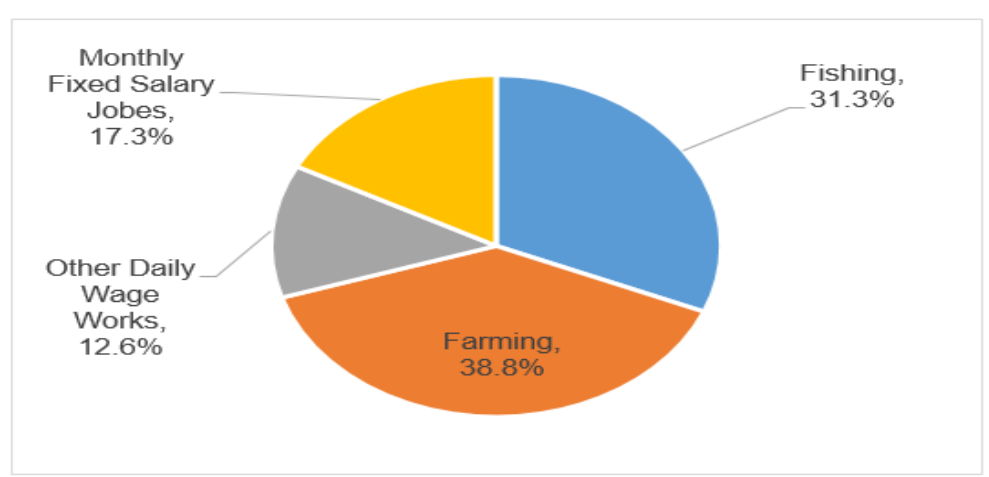

Figure 2: Home garden practitioners and occupations

Thus, the households where it is not headed by a male and people who earn daily wage sell vegetable from home gardens to fulfil their daily needs. Further, the commercialization was very low among those who were more conscious about their health (Fig. 03.b) as they primarily practiced organic crop production system thus, they used compost, green manure, cow dung and poultry manure from back yard farms were used as fertilizer, and the plant extracts were used as a pesticide and weeding were practiced manually. The average home garden size was 0.23 acres, from where the average generated income was Rs. 2,839.00 per month. However, the maximum income worth Rs. 1,981.00 of vegetables per acre were wasted monthly due to post-harvest loss and pest and disease attack. On average, the post-harvest loss was Rs. 548.00. Accordingly, the post-harvest loss of home garden vegetables was $7.4 \%$ which is comparatively very low considering the overall post-harvest loss of Sri Lanka known as 40\% (Institute of Post-Harvest Technology, 2017).

The

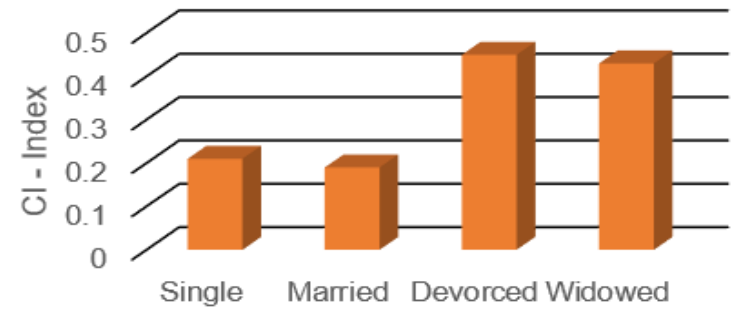

Figure 3.a: Commercialization Index of Female Home gardeners

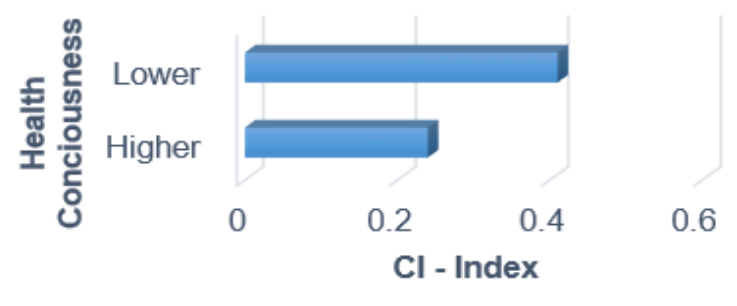

Figure 3.b: Commercialization index and health consciousness

institutional supports for home gardening was very low in Ampara district. About 80 per cent of home gardeners did not get any advice for their vegetable cultivation. Thus, they are practising home garden vegetable cultivation with their own experience. Nevertheless, the home gardeners who gained advice from Agricultural Instructor (Al) and other private extension officers highly commercialized their products (Fig. 04). Therefore, it is essential to enhance government and private institutional advisory services to improve the home garden production, and it may result in a higher level of commercialization in this region.

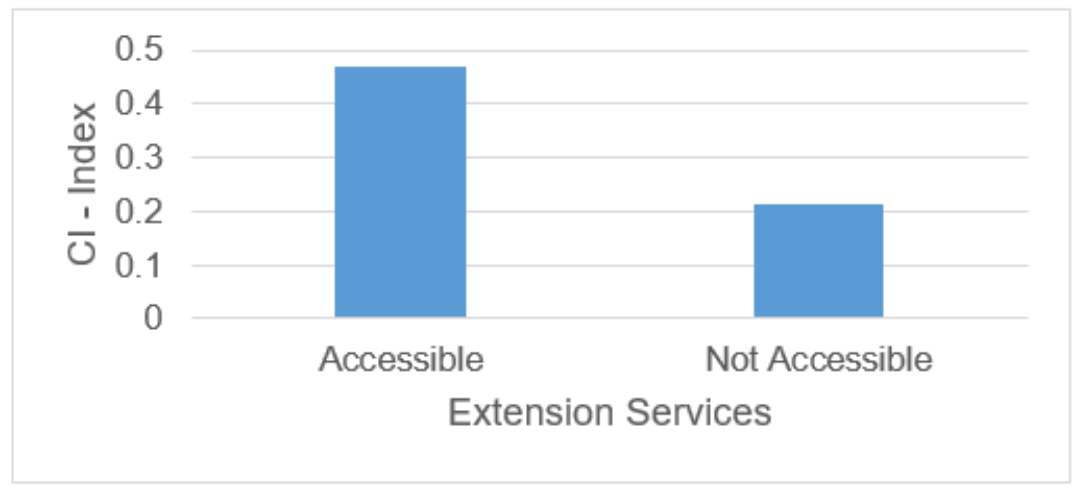

Figure 4: Commercialization index with extension services 
Regression results in Table - 01 show that home garden vegetable commercialization in Ampara district is significantly ( $p<0.05$ ) influenced by farmers' demographics and household characteristics such that; Farmer's educational level, marital status, income from main job number of family labourers and size of the family. Further the losses from pest and disease and institutional support to home gardeners $(p<0.05)$ significantly impacted commercialization. The magnitude of the relationships is presented in Table - 01. The level of education and income from main jobs had a significant negative impact on home garden vegetables' commercialisation. The educated people seek better jobs to cover their living expenses, and a positive relationship was observed between the educational level and the income (Blanden, 2004).

Table 1: Tobit estimates of the determinants of commercializing home garden vegetable in Ampara district

\begin{tabular}{|c|c|c|c|}
\hline Explanatory Variables & Coefficient & Standard Error & P-Value \\
\hline Age & 0.671 & 0.392 & $0.054^{*}$ \\
\hline Gender & 0.324 & 2.273 & 0.945 \\
\hline Education Level & -0.559 & 0.265 & $0.049 * *$ \\
\hline Marital Status & 0.255 & 0.085 & $0.037^{* *}$ \\
\hline Family Income & -0.105 & 0.062 & $0.022^{* *}$ \\
\hline Time Spent for home garden & 0.539 & 0.469 & 0.261 \\
\hline Experience in home gardening & 0.880 & 0.562 & 0.173 \\
\hline No of Family Labour & 0.197 & 0.045 & $0.006^{* * *}$ \\
\hline Size of the Family & -0.390 & 0.155 & $0.015^{* *}$ \\
\hline Dependency Ratio & -0.057 & 0.034 & $0.087^{*}$ \\
\hline Health Consciousness & -0.012 & 0.005 & $0.041^{* *}$ \\
\hline Size of the home garden & 0.006 & 0.012 & 0.50 \\
\hline Post-harvest losses & 0.784 & 0.654 & 0.274 \\
\hline Losses due to pest and disease & -0.671 & 0.031 & $0.024^{* *}$ \\
\hline Time spent for home gardening & 0.426 & 0.357 & 0.189 \\
\hline Distance to Market & 0.823 & 0.579 & 0.143 \\
\hline Retail price of home garden vegetable & 0.346 & 0.233 & 0.141 \\
\hline Retail price of commercial vegetable price & 0.335 & 0.493 & 0.227 \\
\hline Institutional support & 0.432 & 0.036 & $0.026^{* *}$ \\
\hline Constant & 0.478 & 0.179 & 0.149 \\
\hline
\end{tabular}

Pseudo $R^{2}=0.6874$ *** $1 \%, * * 5 \%$ * $10 \%$ level of significance 
The Tobit marital status of the home gardener had a significant negative relationship. According to figure 03.a, the widowed and divorced women marketed their vegetables more than married and single women. Thus divorced and widowed women cover their partial expenses by selling home garden vegetables. Further, the result expresses that the home garden supports the poverty eradication of a community and supports low-income families' sustainable livelihood (Robert \& Tim, 2004; Schreckenberg et al., 2006). The consciousness about health was found to have a significant negative impact on home garden vegetables' commercialisation. The marginal effect indicates that if home gardeners are more conscious of their own health or family health, they increase their consumption level and reduce vegetables' sales. The essential factor is that the institutional supports to home gardeners are another significant variable. The result revealed that the accessibility of extension services from any institution contributes to raising the sales of home garden vegetables. The other salient significant factor was the losses of vegetables due to post pest and disease attack that negatively influenced the commercialisation. Thus, the extension services provide advisory services to protect against pest and disease attack. Therefore, the present study recommends establishing a special extension serviced program.

\section{Conclusion}

This study identified the factors that play significant roles in determining the level of home garden vegetable commercialization. Home gardeners in Ampara district were found to be moderately commercialized. The home garden vegetable cultivation was beneficial to the community's daily wage earners; thus, they commercialized their product more compared to monthly fixed salary earners to support their livelihood activities. Further, home garden vegetables' commercialisation provided a strong back up for the female-headed households, expressly the widowed and divorced females. Furthermore, the home garden vegetable commercialization in Ampara district was negatively influenced by educational level, marital status, family income, family size, dependency ratio, health consciousness and losses due to pests and diseases, where a number of family labour and accessibility of extension services positively influenced. The present study recommends that the female-headed households be motivated to engage in home garden vegetable cultivation by providing inputs and developing market value chains by public and private stakeholders because the role of both public and private sector stakeholders cannot be sufficiently emphasized. Further, the study area needs to be appreciated and promoted via appropriate policy intervention strategies. To further enhance factors that were found critical contributors to increased commercialization, both public and private sector stakeholders will need to provide advisory service to reduce the losses via pest and disease attack.

\section{References}

[1] Abdullah, Rabbi, F., Ahamad, R., Ali, S., Chandio, A. A., Ahmad, W., Ilyas, A., \& Din, I. U. (2019). Determinants of commercialization and its impact on the welfare of smallholder rice farmers by using Heckman's two-stage approach. Journal of the Saudi Society of Agricultural Sciences, 18(2), 224-233. https://doi.org/10.1016/j.jssas. 2017.06.001

[2] Akinlade, R. J., Balogun, O. L., \& Obisesan, A. A. (2016). Commercialization of Urban Vegetable Farming. International Journal of Vegetable Science, 22(1), 24-34. https://doi.org/10.1080/19315260.2014.921266

[3] Babu, S. C., Gajanan, S. N., \& Sanyal, P. (2014). Effects of Commercialization of Agriculture (Shift from Traditional Crop to Cash Crop) on Food Consumption and Nutrition-Application of Chi-Square Statistic. In Food Security, Poverty and Nutrition Policy Analysis (pp. 63-91). Elsevier. https://doi.org/10.1016/B978-0-12-405864-4.00003-X

[4] Blanden, J. (2004). Family Income and Educational Attainment: A Review of Approaches and Evidence for Britain. Oxford Review of Economic Policy, 20(2), 245-263. https://doi.org/10.1093/oxrep/grh014

[5] Dilrukshi, G., Freed, R., \& Karim, M. (2013). Home gardens: a promising approach to enhance household food security and wellbeing. Agriculture \& Food Security, 2(3), 2-13. https://doi.org/https://doi.org/10.1186/2048-7010-2-8

[6] Divisional Secretariat Ampara District. (2018). District development plan 2018-2022. https://www.lk.undp.org/ content/srilanka/en/home/library/democratic_governance/The-Five-Year-Ampara-District-Development-Plan.html

[7] Govereh, J., Jayne, T., \& Nyoro, J. (1999). Smallholder commercialization, interlinked markets and food pro-ductivity: Cross country evidence in Eastern and Southern Africa.

[8] Hebard, A. (2016). Successful Commercialization of Industrial Oil Crops. In Industrial Oil Crops (pp. 343-358). Elsevier. https://doi.org/10.1016/B978-1-893997-98-1.00012-9

[9] Hoogerbrugge, I., \& Fresco, L. O. (1993). Homegarden systems: Agricultural characteristics and challenges.

[10] Institute of Post Harvest Technology. (2017). Annual report-2016. https://www.parliament.lk/uploads/ documents/aperspresented/annualreport-institute-of-post-harvest-technology-2016.pdf

[11] Jerop, R., Owuor, G., \& Mshenga, P. (2018). Finger Millet Output Commercialization Among Smallholder Farmers: Role of Agricultural Innovations in Kenya. European Jounal of Business Management, 10(27), 91-100.

[12] Kabiti, H. M., Raidimi, N. E., Pfumayaramba, T. K., \& Chauke1, P. K. (2016). Determinants of Agricultural Commercialization among Smallholder Farmers in Munyati Resettlement Area, Chikomba District, Zimbabwe. Journal of Human Ecology, 53(1), 10-19. https://doi.org/10.1080/09709274.2016.11906951

[13] Liu, X., Wang, Z., \& Wu, Y. (2013). Group variable selection and estimation in the tobit censored response model. Computational Statistics \& Data Analysis, 60(1), 80-89. https://doi.org/10.1016/j.csda.2012.10.019

[14] Mariyono, J. (2018). Profitability and Determinants of Smallholder Commercial Vegetable Production. International Journal of Vegetable Science, 24(3), 274-288. https://doi.org/10.1080/19315260.2017.1413698

[15] Mariyono, J., Kuntaringsih, A., Dewi, H. A., Latifah, E., Daroini, P. B., Negoro, A. A., Afari-sefa, V., \& Luther, G. (2017). Pathway analysis of vegetable farming commercialization in Indonesia. Economic Journal of Emerging Markets, 9(2), 115-124. 
https://doi.org/10.20885/ejem.vol9.iss2.art1

[16] Maumburudze, D., Mutambara, J., Mugabe, P., \& Manyumwa, H. (2016). Prospects for commercialization of indigenous chickens in Makoni District, Zimbabwe. Livestock Research for Rural Development, 28(4), 64-73.

[17] Moreki, J. C., \& Radikara, M. V. (2013). Challenges to commercialization of guinea fowl in Africa. International Journal of Science and Research, 02(11), 436-440.

[18] Mufeet, M. ., Korale-Gedara, P. ., Silva, G. L. L. ., \& Rathnasekara, H. (2018). Determinants of commercialization of indigenous poultry production: A case in Ampara district. Sri Lanka Journal of Animal Production, 10(1), 37-43.

[19] Mufeeth, M. M., Korale, K. P., \& Rthnasekara, H. (2015). Determinants of commercialization of indigenous chicken. Faculty of Agriculture Undergraduate Research Symposium, 189.

[20] Niñez, V. (1987). Household gardens: Theoretical and policy considerations. Agricultural Systems, 23(3), 167-186. https://doi.org/10.1016/0308-521X(87)90064-3

[21] Ochieng, J., Knerr, B., Owuor, G., \& Ouma, E. (2016). Commercialisation of Food Crops and Farm Productivity: Evidence from Smallholders in Central Africa. Agrekon, 55(4), 458-482. https://doi.org/10.1080/03031853.2016. 1243062

[22] Osmani, G., Islam, K., Ghosh, C., \& Hossain, E. (2014). Commercialization of smallholder farmers and its welfare outcomes: Evidence from Durgapur Upazila of Rajshahi District, Bangladesh. Journal of World Economic Research, 3(6), 119-126.

[23] Pingali, P. L., \& Rosegrant, M. W. (1995). Agricultural commercialization and diversification: processes and policies. Food Policy, 20(3), 171185. https://doi.org/10.1016/0306-9192(95)00012-4

[24] Reginald, T., Holm, U., \& Emmanuel, A. (2012). Homegardens as a Source of Income for Rural Households—A Case Study of Bieha District, Southern Burkina Faso. Journal of Agricultural Science and Technology, 2, 798-813.

[25] Robert, M., \& Tim, H. (2004). Small homegarden plots and sustainable livelihoods for the poor (11).

[26] Rubhara, T., \& Mudhara, M. (2019). Commercialization and its determinants among smallholder farmers in Zimbabwe. A case of Shamva District, Mashonaland Central Province. African Journal of Science, Technology, Innovation and Development, 11(6), 711-718. https://doi.org/10.1080/20421338.2019.1571150

[27] Schreckenberg, K., Awono, A., Degrande, A., Mbosso, C., Ndoye, O., \& Tchoundjeu, Z. (2006). Domesticating indigenous fruit trees as a contribution to poverty reduction. Forests, Trees and Livelihoods, 16(1), 35-51. https://doi.org/10.1080/14728028.2006.9752544

[28] Strasberg, P. J., Jayne, T. S., Yamano, T., Nyoro, J. K., Karanja, D. D., \& Strauss, J. (1999). Effects of agricultural commercialization on food crop input use and productivity in Kenya (No. 71; Food Security International Development Working Papers). https://doi.org/10.22004/ag.econ.54675

[29] Walker, N. L., Norton, A., Harris, I., Williams, A. P., \& Styles, D. (2019). Economic and environmental efficiency of UK and Ireland water companies: Influence of exogenous factors and rurality. Journal of Environmental Management, 241(March), 363-373. https://doi.org/10.1016/j.jenvman.2019.03.093

[30] Wooldridge, J. M. (2013). The tobit model for corner solution responses. In Introductory Econometrics: A Modern Approachodern approach (5th ed., pp. 596-604). Cengage Learning. 